\title{
Antihypertensive effect of casein hydrolysate in a placebo-controlled study in subjects with high-normal blood pressure and mild hypertension
}

\author{
Seiichi Mizuno ${ }^{1}$, Keiichi Matsuura ${ }^{1}$, Takanobu Gotou ${ }^{1}$, Shingo Nishimura $^{1}$, Osami Kajimoto ${ }^{2}$, \\ Mitsuharu Yabune ${ }^{2}$, Yoshitaka Kajimoto ${ }^{2}$ and Naoyuki Yamamoto ${ }^{1 *}$ \\ ${ }^{1}$ Food Research Laboratory, Calpis Co. Ltd. Sagamihara, Kanagawa, Japan \\ ${ }^{2}$ Soiken Inc., Toyonaka, Osaka, Japan \\ (Received 29 April 2004 - Revised 6 January 2005 - Accepted 10 January 2005)
}

\begin{abstract}
We describe a clinical trial to study the efficacy of a casein hydrolysate, prepared using an Aspergillus oryzae protease, containing the major angiotensin-I-converting enzyme inhibitory peptides Val-Pro-Pro (VPP) and Ile-Pro-Pro (IPP) in a single-blind, placebo-controlled study. A total of 131 volunteers with high-normal blood pressure and mild hypertension were randomly divided into four groups (n 32 or 33 in each group). Each volunteer was given two tablets containing four different dosages of VPP and IPP (VPP + IPP: 0, 1.8, 2.5 and $3.6 \mathrm{mg}$ ), daily for 6 weeks. A significant decrease in systolic blood pressure was observed at 6 weeks in the active group receiving $1.8 \mathrm{mg}(P<0.01)$ VPP and IPP; in the active groups receiving either $2.5 \mathrm{mg}$ or $3.6 \mathrm{mg}$, systolic blood pressure was decreased at both 3 weeks $(P<0.05$ and $P<0.05)$ and 6 weeks $(P<0.001$ and $P<0.0001)$ compared with systolic blood pressure measured before treatment. Changes in the systolic blood pressure after 6 weeks of treatment in the four groups were $-1 \cdot 7$, $-6 \cdot 3,-6.7$ and $-10 \cdot 1 \mathrm{mmHg}$, and these effects were dose dependent. In addition, a significant difference in systolic blood pressure between the placebo group and the VPP and IPP group receiving $3.6 \mathrm{mg}$ was observed $(P<0.001)$ by two-way ANOVA. The antihypertensive effect was greater in mildly hypertensive subjects ( $n 20$ or 21 in each group) than in any of the other subjects. No significant change of diastolic blood pressure was observed for all the test groups, and no differences in diastolic blood pressure in the test sample groups compared with the placebo group were observed during the test period.
\end{abstract}

Antihypertensive effect: Clinical study: Casein hydrolysate: VPP and IPP

Hypertension is a risk factor in various CVD, such as arteriosclerosis and cardiac infarction. Maintaining blood pressure within the normal range is very important in reducing the risk of these CVD. Many antihypertensive agents have been developed to reduce the risk for hypertensive patients (Atkinson et al. 1980; Ferguson et al. 1980; Staessen 1981; Stornello et al. 1983), and daily diets have been reported in order to help control blood pressure; these include Dietary Approaches to Stop Hypertension, which recommends vegetable, fruits and low-fat dairy foods (Svetkey et al. 2001; Conlin et al. 2000; Moore et al. 1999). Furthermore, many antihypertensive peptides have been isolated from various hydrolysates of food proteins (Maruyama et al. 1985; Miyoshi et al. 1991; Yokoyama et al. 1992; Matsumura et al. 1993). Most of these peptides have the inhibitory activity of angiotensin-I-converting enzyme (ACE, kininase II; EC 3.4.15.1), which plays an important role in the regulation of blood pressure by catalysing the production of a vasoconstrictor, angiotensin II, and inactivating a vasodilator, bradykinin (reviewed in Meisel \& Bockelmann, 1999; Takano, 1998; Yamamoto \& Takano, 1999; Yamamoto et al. 2003). The antihypertensive effects of ACE inhibitory peptides have been proven using Lactobacillus helveticus-fermented milk in hypertensive subjects (Hata et al. 1996), in a pilot study (Seppo et al. 2002), over a long-time period (Seppo et al. 2003) and with an enzymatic hydrolysate of a sardine protein (Kawasaki et al. 2000).

In our previous study, the ACE inhibitory peptides Val-Pro-Pro (VPP) and Ile-Pro-Pro (IPP) were isolated from casein by the proteolysis of L. helveticus through fermentation (Nakamura et al. $1995 a, b$ ). Among lactic acid bacteria-fermented milks, the antihypertensive effect was specific to the L. helveticus-fermented milk in a study using spontaneously hypertensive rats (Yamamoto et al. 1994; Masuda et al. 1996; Nakamura et al. 1996). A functional food product processed from L. helveticus-fermented milk was proven to have an antihypertensive effect in a clinical trial and is recognised as a Foods for Specified Health Uses product in Japan. However, L. helveticus-fermented milk still contains much unhydrolysed casein, and the productivity of VPP and IPP by milk fermentation is limited. A new enzymatic method for manufacturing these two peptides from casein was recently developed using an Aspergillus oryzae protease (Mizuno et al. 2004).

Peptide material produced by the A. oryzae protease (A. oryzae hydrolysate) has advantages over L. helveticus-fermented milk in that the production cost is lower and the applications are more versatile. It is, however, necessary to determine the clinical efficacy of the $A$. oryzae hydrolysate in order to evaluate 
the possibility of use in hypertensive subjects because the peptide profile differs from that of $L$. helveticus-fermented milk. The aim of the present study was to investigate the effect of the A. oryzae hydrolysate containing the ACE inhibitory peptides VPP and IPP on subjects with high-normal blood pressure and mild hypertension, as defined by the World Health Organization/International Society of Hypertension in 1999, using a single-blind, placebocontrolled study (Chalmers et al. 1999). In this clinical study, the antihypertensive effects of the A. oryzae hydrolysate, using four different dosages, were studied.

\section{Materials and methods}

Screening

Participants with a systolic blood pressure (SBP) of $130-159 \mathrm{mmHg}$ and a diastolic blood pressure (DBP) of $85-99 \mathrm{mmHg}$ treated for more than 2 months in the Souiken Clinic in Osaka in a previous analysis were recruited from the clinic's database. A total of 136 clinically healthy volunteers, aged between 30 and 57 years, not taking any medication containing antihypertensive agents and who were categorised as having high-normal blood pressure (SBP $120-139 \mathrm{mmHg}$ ), and mildly hypertensive (SBP $140-159 \mathrm{mmHg}$ ) volunteers based on the World Health Organization/International Society of Hypertension (Chalmers et al. 1999) definition, were selected. Five subjects withdrew for personal reasons, leaving 131 eligible subjects: fifty-two men and seventy-nine women (forty-eight high-normal blood pressure and eighty-three mild hypertension). Subjects were divided into four groups for different dosages of the $A$. oryzae hydrolysates, without any significant difference in age, blood pressure, pulse rate, standing height, body weight or obesity index (Table 1). Subjects were excluded if any of the following exclusion criteria were present: secondary hypertension, an allergy to milk, chronic drinking, diabetes, pregnancy, severe anaemia, severe diseases or constant use of oral medication or supplements affecting blood pressure. All subjects were given an explanation of the purpose of this study, and once they understood the details sufficiently, they were asked to sign a consent form for the study. This study was approved by the Joint Institutional Review Board of Soiken, Inc. and Soiken Clinic (both Osaka, Japan).

\section{Preparation of test samples}

The A. oryzae hydrolysate for test samples was prepared by casein hydrolysis of the A. oryzae protease, as described in a previous paper (Mizuno et al. 2004), with slight modification. Briefly, sodium caseinate was dissolved in hot water $\left(90^{\circ} \mathrm{C}\right)$ adjusting the $\mathrm{pH}$ to 7.0 by adding $\mathrm{NaOH}$ to a final concentration of $15 \%(\mathrm{w} / \mathrm{v})$ and cooled to $50^{\circ} \mathrm{C}$ (casein solution). Enzyme isolated from $A$. oryzae (Sumizyme FP; Shinnihon Chemical Co. Ltd, Aichi, Japan) was then dissolved in water at $20 \%(\mathrm{w} / \mathrm{v})$, added to the casein solution to a final concentration of $0.6 \%$ and incubated at $50^{\circ} \mathrm{C}$ for $14 \mathrm{~h}$. After the reaction, proteolytic enzyme in the casein hydrolysate was inactivated by heating at $100^{\circ} \mathrm{C}$ for $30 \mathrm{~s}$, concentrated and spray-dried into powder (A. oryzae hydrolysate).

Table 1. Baseline characteristics of study subjects

(Mean values and standard deviations)

\begin{tabular}{|c|c|c|c|c|c|c|c|c|c|}
\hline \multirow[b]{2}{*}{ Characteristic } & & \multirow[b]{2}{*}{ Placebo group } & \multirow[b]{2}{*}{ SD } & \multicolumn{6}{|c|}{ Test group (VPP + IPP) } \\
\hline & & & & $1.8 \mathrm{mg}$ & SD & $2.5 \mathrm{mg}$ & SD & $3.6 \mathrm{mg}$ & SD \\
\hline \multirow[t]{3}{*}{$n$} & Total & 32 & & 33 & & 33 & & 33 & \\
\hline & High-normal & 12 & & 12 & & 12 & & 12 & \\
\hline & Mild hypertension & 20 & & 21 & & 21 & & 21 & \\
\hline \multirow[t]{2}{*}{ Male:female } & Total & $13: 19$ & & $14: 19$ & & $12: 21$ & & $13: 20$ & \\
\hline & High-normal & $3: 9$ & & $3: 9$ & & $3: 9$ & & $3: 9$ & \\
\hline \multirow[t]{3}{*}{ Age (years) } & Total & $44 \cdot 7$ & $13 \cdot 6$ & $42 \cdot 7$ & $13 \cdot 6$ & 44.9 & $13 \cdot 0$ & $44 \cdot 7$ & 12.99 \\
\hline & High-normal & $42 \cdot 6$ & $12 \cdot 1$ & $47 \cdot 3$ & $8 \cdot 7$ & $50 \cdot 2$ & $13 \cdot 0$ & 42.9 & $12 \cdot 39$ \\
\hline & Mild hypertension & $46 \cdot 0$ & $14 \cdot 7$ & $40 \cdot 1$ & $15 \cdot 3$ & $41 \cdot 8$ & $12 \cdot 2$ & $45 \cdot 8$ & 13.51 \\
\hline \multirow[t]{3}{*}{ Height $(\mathrm{cm})$} & Total & 163 & $9 \cdot 0$ & $161 \cdot 7$ & $10 \cdot 2$ & $161 \cdot 3$ & 8.9 & $162 \cdot 1$ & $9 \cdot 2$ \\
\hline & High-normal & $160 \cdot 9$ & $7 \cdot 8$ & $158 \cdot 7$ & 9.2 & 159.5 & $8 \cdot 1$ & $158 \cdot 2$ & 7.4 \\
\hline & Mild hypertension & $164 \cdot 3$ & $9 \cdot 7$ & 163.4 & $10 \cdot 5$ & $162 \cdot 2$ & $9 \cdot 3$ & $164 \cdot 3$ & 9.5 \\
\hline \multirow[t]{2}{*}{ Body weight $(\mathrm{kg})$} & Total & $62 \cdot 1$ & 8.9 & $62 \cdot 6$ & $15 \cdot 9$ & 61.5 & $10 \cdot 7$ & 62.5 & $12 \cdot 3$ \\
\hline & High-normal & $62 \cdot 0$ & $7 \cdot 5$ & 64.0 & $22 \cdot 0$ & $59 \cdot 8$ & 11.5 & 64.9 & $14 \cdot 1$ \\
\hline \multirow{2}{*}{ BMI $\left(\mathrm{kg} / \mathrm{m}^{2}\right)$} & High-normal & $24 \cdot 0$ & $3 \cdot 0$ & $25 \cdot 0$ & $6 \cdot 1$ & 23.5 & $4 \cdot 0$ & $25 \cdot 9$ & $5 \cdot 0$ \\
\hline & Mild hypertension & 23.0 & 2.9 & $23 \cdot 1$ & $3 \cdot 1$ & $23 \cdot 7$ & 3.6 & 22.5 & $2 \cdot 8$ \\
\hline \multirow[t]{3}{*}{$\mathrm{SBP}(\mathrm{mmHg})$} & Total & 143.6 & $9 \cdot 3$ & $144 \cdot 2$ & $8 \cdot 3$ & $143 \cdot 6$ & $8 \cdot 0$ & $143 \cdot 7$ & 8.6 \\
\hline & High-normal & $133 \cdot 2$ & 2.5 & 134.8 & $2 \cdot 2$ & 134.5 & $2 \cdot 6$ & $134 \cdot 2$ & $2 \cdot 8$ \\
\hline & Mild hypertension & $149 \cdot 8$ & $5 \cdot 3$ & $149 \cdot 6$ & $5 \cdot 0$ & $148 \cdot 8$ & 4.5 & $149 \cdot 1$ & $5 \cdot 4$ \\
\hline \multirow[t]{3}{*}{$\mathrm{DBP}(\mathrm{mmHg})$} & Total & $86 \cdot 2$ & $5 \cdot 4$ & $86 \cdot 4$ & $5 \cdot 9$ & $86 \cdot 0$ & $6 \cdot 0$ & $86 \cdot 1$ & $5 \cdot 9$ \\
\hline & High-normal & 81.6 & $2 \cdot 2$ & 81.9 & 4.9 & $81 \cdot 7$ & 3.5 & $81 \cdot 6$ & 4.6 \\
\hline & Mild hypertension & 89.0 & 4.9 & 88.9 & $4 \cdot 8$ & 88.5 & $5 \cdot 6$ & $88 \cdot 6$ & $5 \cdot 0$ \\
\hline \multirow[t]{3}{*}{ Pulse rate (beats/min) } & Total & 69.5 & 4.4 & $68 \cdot 4$ & $6 \cdot 3$ & $69 \cdot 3$ & 4.4 & 68.4 & 4.9 \\
\hline & High-normal & $69 \cdot 3$ & $4 \cdot 0$ & $69 \cdot 0$ & $6 \cdot 7$ & $68 \cdot 8$ & $4 \cdot 6$ & $68 \cdot 7$ & 4.5 \\
\hline & Mild hypertension & 69.6 & $4 \cdot 7$ & $68 \cdot 1$ & $6 \cdot 1$ & 69.5 & 4.4 & $68 \cdot 2$ & $5 \cdot 3$ \\
\hline
\end{tabular}

IPP, lle-Pro-Pro; VPP, Val-Pro-Pro; SBP, systolic blood pressure; DBP, diastolic blood pressure. No significant difference was observed between the groups. 
VPP and IPP in the A. oryzae hydrolysate were measured as the major active components using a liquid chromatography mass spectrometry method, described in a previous report (Matsuura et al. 2005). Dairy dosage was calculated as the sum of the two active peptides, VPP and IPP. Aspergillus oryzae hydrolysate containing $0,1.8,2.5$ or $3.6 \mathrm{mg}$ of the two peptides was blended with sweeteners and flavourings before being made into tablets (Table 2). Amino nitrogen in the A. oryzae hydrolysate was analysed as protein content, and the amino nitrogen levels in all the samples, including the placebo sample, were adjusted to the same levels by adding sodium caseinate as a nitrogen source (Table 2).

\section{Study design}

A randomised, single-blind, placebo-controlled study was conducted over an 8 -week period, consisting of a 2 -week pretreatment period and a 6-week treatment period. Subjects in the placebo group (n 32), test sample group 1 ( $n$ 33), test sample group 2 ( $n$ 33) and test sample group 3 ( $n$ 33) were requested to ingest two tablets containing $0,1.8,2.5$ or $3.6 \mathrm{mg}$ VPP and IPP, respectively, with every breakfast for 6 weeks. In addition, subjects were also requested not to change their daily lifestyle, including smoking and exercising, except if taking dairy products or health foods with blood pressure-lowering effects.

Measurements of blood pressure, pulse rate, body weight and standing height, and a medical examination, were performed at the Soiken Clinic on all subjects at 2 weeks before and at $0,1,3$ and 6 weeks after the start of treatment. To measure these parameters, all subjects were requested to visit the clinic to measure their blood pressure without taking test samples. All medical examinations were performed by a medical doctor. Blood pressure was the average value of three measurements taken in the morning (each by a trained nurse), in a sitting position, using a mercury sphygmomanometer after at least 10 min rest. Blood specimens were taken at 0 and 6 weeks of treatment. Urea nitrogen, creatin, uric acid, electrolytes $\left(\mathrm{Na}^{+}, \mathrm{K}^{+}, \mathrm{Cl}^{-}, \mathrm{Ca}^{2+}\right.$ and $\left.\mathrm{Mg}^{2+}\right)$, glutamic-oxaloacetic transaminase, glutamic-pyruvic transaminase, alkaline phosphatase, $\gamma$-glutamyltranspeptidase,

Table 2. Nutrition composition of the placebo and test samples

\begin{tabular}{|c|c|c|c|c|}
\hline & \multirow[b]{2}{*}{ Placebo group } & \multicolumn{3}{|c|}{ Test group (VPP + IPP) } \\
\hline & & $1.8 \mathrm{mg}$ & $2.5 \mathrm{mg}$ & $3.6 \mathrm{mg}$ \\
\hline Energy $(\mathrm{kJ} / \mathrm{d})$ & $60 \cdot 7$ & $60 \cdot 7$ & $60 \cdot 7$ & $60 \cdot 7$ \\
\hline Energy (kcal/d) & $14 \cdot 5$ & $14 \cdot 5$ & 14.5 & 14.5 \\
\hline Moisture (mg/d) & $28 \cdot 8$ & $28 \cdot 8$ & $32 \cdot 4$ & $32 \cdot 4$ \\
\hline Proteint $(\mathrm{g} / \mathrm{d})$ & 0.55 & 0.52 & 0.51 & 0.49 \\
\hline Fat $(g / d)$ & $0 \cdot 10$ & $0 \cdot 10$ & 0.10 & 0.10 \\
\hline Carbohydrate (g/d) & $2 \cdot 8$ & $2 \cdot 8$ & $2 \cdot 8$ & 2.9 \\
\hline Ash (g/d) & $32 \cdot 4$ & $32 \cdot 4$ & $32 \cdot 4$ & $32 \cdot 4$ \\
\hline Fibre $(g / d)$ & 0.09 & 0.08 & 0.08 & 0.09 \\
\hline $\mathrm{Na}^{+}(\mathrm{mg} / \mathrm{d})$ & $6 \cdot 8$ & $7 \cdot 6$ & 7.9 & $8 \cdot 3$ \\
\hline $\mathrm{K}^{+}(\mathrm{mg} / \mathrm{d})$ & 1.0 & 1.0 & $1 \cdot 1$ & $1 \cdot 2$ \\
\hline $\mathrm{Ca}^{2+}(\mathrm{mg} / \mathrm{d})$ & $4 \cdot 3$ & $4 \cdot 3$ & $4 \cdot 3$ & $4 \cdot 3$ \\
\hline $\mathrm{Mg}^{2+}(\mathrm{mg} / \mathrm{d})$ & 0.11 & 0.14 & 0.14 & 0.18 \\
\hline$P(\mathrm{mg} / \mathrm{d})$ & $6 \cdot 12$ & $6 \cdot 12$ & $6 \cdot 12$ & $6 \cdot 12$ \\
\hline $\operatorname{VPP}(\mathrm{mg} / \mathrm{d})$ & ND & 0.89 & $1 \cdot 27$ & 1.86 \\
\hline $\operatorname{IPP}(\mathrm{mg} / \mathrm{d})$ & ND & 0.86 & $1 \cdot 2$ & 1.76 \\
\hline
\end{tabular}

IPP, Ile-Pro-Pro; VPP, Val-Pro-Pro; ND, not determined.

†Protein: amino nitrogen contents in all samples were analysed and adjusted to the same level by adding sodium caseinate. lactate dehydrogenase, total bilirubin, peripheral blood (leucocyte count, erythrocyte count, mean corpuscular haemoglobin, haematocrit, mean corpuscular volume, mean corpuscular haemoglobin concentration, platelet count), total protein, albumin, albumin:globulin ratio, blood glucose, haemoglobin $\mathrm{A}_{1 \mathrm{c}}$, total cholesterol, HDL-cholesterol and triacylglycerol measurements were obtained from blood samples.

\section{Statistical analyses}

All measured values represent means and standard deviations in the tables, and means and standard errors in the figures. Blood pressure and pulse rate for each test group were compared with those of the placebo group during the test period, and analysed using two-way ANOVA. SPSS Version 10 (SPSS Inc. Co. Ltd, Chicago, IL, USA) was used for statistical analysis and was considered as statistically significant if $P<0.05$ resulted from a two-tailed test analysis. Changes in blood pressure, pulse rate, body weight and BMI after treatment were analysed by a paired Student's $t$-test for each subject from the starting value.

\section{Results}

\section{Subjects and demographics}

A total of 131 eligible subjects (fifty-two men and seventy-nine women; forty-eight with high-normal normal blood pressure and eighty-three with mild hypertension) were randomly allocated into four groups. The demographic and total characteristics of the four groups are listed in Table 1. No significant differences were observed between the four groups of both high-normal blood pressure and mildly hypertensive subjects with respect to gender, age, SBP, DBP, BMI, body weight, height, and pulse rate.

\section{Blood pressure response in all subjects}

Changes in blood pressure (SBP and DBP) in subjects with highnormal blood pressure and mild hypertension in the test and placebo groups are presented in Fig. 1. A significant decrease in SBP (a fall of $5.8 \mathrm{mmHg}$ ) was observed in the group receiving $1.8 \mathrm{mg}$ VPP and IPP at 6 weeks $(P<0 \cdot 01)$ when compared with the value at week 0 . Significant decreases were also observed in the groups receiving $2.5 \mathrm{mg}$ and $3.6 \mathrm{mg}$ VPP and IPP at 3 weeks (decreases of 3.4 and $4.1 \mathrm{mmHg} ; P<0.05$ and $P<0.05$, respectively) and 6 weeks (decreases of 6.2 and $9.3 \mathrm{mmHg} ; P<0.001$ and $P<0.0001$, respectively) when compared with the value at week 0 . In addition, a significant difference between the placebo group and the A. oryzae peptide-intake group was observed at a dosage of $3.6 \mathrm{mg}$ $(P<0.001)$ by two-way ANOVA. No significant differences were observed between the placebo group and A. oryzae peptide-intake groups at dosages of 1.8 and $2.5 \mathrm{mg}$. No significant differences in DBP or pulse rate were observed between the placebo group and any of the A. oryzae peptide-intake groups (Fig. 1). There were also no significant differences in the changes in each blood pressure value during the test period (data not shown).

\section{Blood pressure response in groups with high-normal blood pressure or mild hypertension}

In this study, twelve subjects in each group had high-normal blood pressure, and SBP averages in the four groups were 


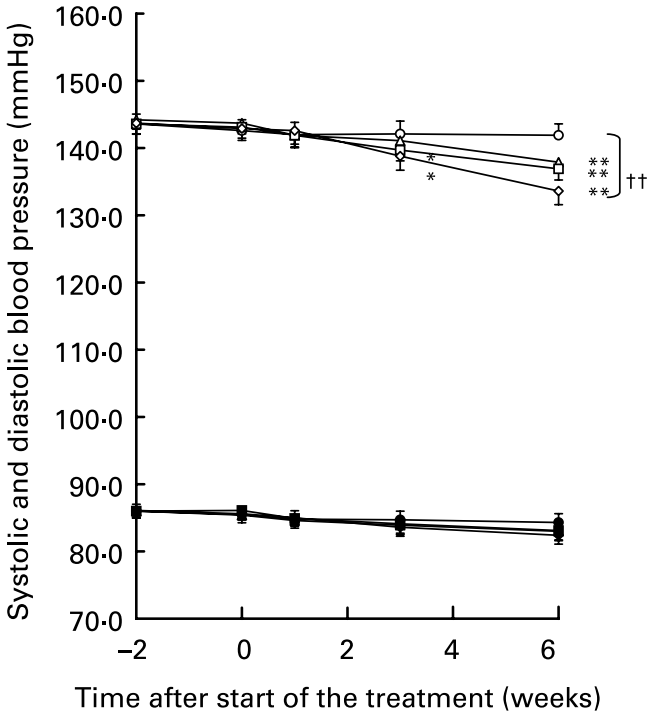

Fig. 1. Changes in systolic and diastolic blood pressure in subjects with highnormal blood pressure and mild hypertension with four dosages of casein hydrolysate prepared with Aspergillus oryzae protease. Systolic $(\bigcirc, \triangle, \diamond, \square)$ and diastolic $(\bullet, \mathbf{\Lambda}, \mathbf{\square})$ blood pressure were measured at $-2,0,1,3$ and 6 weeks with respect to starting the intake. The sum of the concentrations of Val-Pro-Pro and Ile-Pro-Pro were $0 \mathrm{mg}(\bigcirc$ and $\bullet$ ), $1.8 \mathrm{mg}(\triangle$ and $\boldsymbol{\Delta}), 2.5 \mathrm{mg}$ $(\diamond$ and $\diamond$ ) and $3.6 \mathrm{mg}$ ( $\square$ and $\square$ ). Mean values were significantly different from starting values $\left({ }^{*} P<0.05,{ }^{\star \star} P<0.01\right.$ and $\left.{ }^{\star \star *} P<0.001\right)$ and also from the control group $(\dagger P<0.05$ and $\dagger \dagger P<0.01)$.

133.2-134.8 mmHg. The subjects' average SBP ( $n 20$ or 21 ) fell within the range $148.8-149.8$ if mildly hypertensive subjects were selected for the analysis. Statistical analysis was carried out for each of the two groups (high-normal and mildly hypertensive groups).

In the analysis of the mildly hypertensive subjects, significant differences in SBP were observed after 3 weeks' administration of $2.5 \mathrm{mg}$ and $3.6 \mathrm{mg}$ VPP and IPP $(-4.4$ and $-6.1 \mathrm{mmHg}, P<0.05$ and $P<0 \cdot 01$, respectively), and after 6 weeks' administration of $1.8,2.5$ and $3.6 \mathrm{mg}$ VPP and IPP $(-8.4,-8.9$ and $-13.0 \mathrm{mmHg}$; $P<0.01, P<0.01$ and $P<0.001$, respectively; Table 3) compared with the values before treatment. Moreover, a significant difference in SBP was observed during the treatment of mildly hypertensive subjects with $3.6 \mathrm{mg}$ of VPP and IPP when compared with the placebo group, using two-way ANOVA. A significant difference in DBP was also observed in mildly hypertensive subjects 3 weeks after treatment with $1.8 \mathrm{mg}$ VPP and IPP and 6 weeks after treatment with $3.6 \mathrm{mg}$ VPP and IPP, compared with values before treatment (Table 3). However, no significant difference was observed in DBP between the placebo group and any A. oryzae peptide-intake group for the mildly hypertensive subjects.

No significant difference was observed between the pulse rate of the placebo group and of any of the A. oryzae peptide-intake groups, but the pulse rate was significantly higher in the group treated with $1.8 \mathrm{mg}$ VPP and IPP 1 week after the start of treatment (data not shown). There were, however, no other relevant parameters linked to this change of pulse rate.

No significant differences were observed in SBP, DBP and pulse rate between the placebo group and high-normal blood pressure subjects in the VPP and IPP intake groups, using ANOVA (Table 3). In addition, there were no significant changes in SBP, DBP and pulse rate during the treatment period compared with the starting value.
Body weight, BMI and haematological study

Changes in body weight, BMI, haematology parameters and blood biochemistry measured before and after treatment for all volunteers are shown in Tables 1 and 4. Body weight and BMI were significantly decreased after 1 week of treatment in the placebo group and the $2.5 \mathrm{mg}$ two-peptide-intake group, in comparison to the values before treatment, but there were no significant changes in the other groups during treatment. Table 4 details the results of the haematology and blood biochemistry study performed before and after treatment. Significant changes were observed at 6 weeks in all groups with respect to $\mathrm{Na}^{+}$, albumin, albumin:globulin ratio and haemoglobin $\mathrm{A}_{\mathrm{IC}}$ level compared with the values before treatment. The concentration of $\mathrm{K}^{+}$in the $2.5 \mathrm{mg}$ two-peptide-intake group was significantly higher than that in the placebo group at 6 weeks after treatment. However, all of these changes remained within the normal range, and there were no abnormal variations.

\section{Treatment-related adverse events}

During the 6 weeks of treatment, a few minor adverse events were observed in all groups. Nine subjects (six in the placebo group and three in the peptide groups) caught colds, four (two in the placebo group and two in the peptide groups) had diarrhoea, one subject (peptide groups) developed constipation, and two (one in the placebo group and one in the peptide groups) had pruritis. These symptoms were, however, seen in both the peptide and the placebo groups; all the subjects recovered during treatment, and the conditions were not considered to be treatment related. No dry coughs or skin and gastrointestinal symptoms were observed.

\section{Discussion}

Dose-dependent antihypertensive effects of various bioactive peptides have been reported in animal studies (Nakamura et al. 1995b; Maeno et al. 1996; Yamamoto et al. 1999). However, dose-dependent effects of these antihypertensive peptides have not yet been studied in hypertensive subjects. In this study, significant decreases in SBP $(5.8,6.2$ and $9.3 \mathrm{mmHg}$, respectively) were detected for all subjects with dosages of VPP and IPP ranging from 1.8 to $3.6 \mathrm{mg}$ at 6 weeks after treatment. These effects, detected by repeated ingestions of an A. oryzae hydrolysate, were slight, but clear dose-dependent effects were measured for four different dosages, ranging from 0 to $3.6 \mathrm{mg}$ VPP and IPP, over a 6-week treatment period. Moreover, no limitation of the antihypertensive effect was observed with increasing dosages in this study, even when the highest peptide dosage $(3.6 \mathrm{mg})$ was ingested. Therefore, a stronger blood pressure-lowering effect on hypertensive subjects may be expected as the dosage of the two peptides increases or the treatment period is prolonged. Increases in the dosage of VPP and IPP could be easily controlled in the final product if the A. oryzae hydrolysate were used, although it would be difficult with the conventional L. helveticus-fermented milk.

The A. oryzae hydrolysate has a different composition of VPP and IPP compared with $L$. helveticus-fermented milk (Hata et al. 1996). The ratio of VPP and IPP concentrations (VPP/IPP) in A. oryzae was previously approximated to 1 , whereas in $L$. helveticus-fermented milk it was approximately 2 . However, the total amount of ACE inhibitory activity of VPP and IPP in the 
Table 3. Changes in systolic and diastolic blood pressure in the groups with mild hypertension and high-normal blood pressure (Values are means with standard deviations)

\begin{tabular}{|c|c|c|c|c|c|c|c|c|c|c|c|c|c|}
\hline \multirow[b]{2}{*}{ Subject } & \multirow{2}{*}{$\begin{array}{c}\text { Dosage of VPP } \\
\text { and IPP (mg) }\end{array}$} & \multirow[b]{2}{*}{$n$} & \multicolumn{10}{|c|}{ Blood pressure at each week after the treatment $(\mathrm{mmHg})$} & \multirow{2}{*}{$\begin{array}{l}\text { ANOVA } \\
\text { analysis }\end{array}$} \\
\hline & & & -2 & SD & 0 & SD & 1 & $\mathrm{SD}$ & 3 & SD & 6 & SD & \\
\hline & 0.0 & 20 & $149 \cdot 8$ & $5 \cdot 3$ & $148 \cdot 4$ & $7 \cdot 6$ & $147 \cdot 7$ & $10 \cdot 6$ & $148 \cdot 0$ & $10 \cdot 3$ & $147 \cdot 2$ & $10 \cdot 8$ & \\
\hline & 1.8 & 21 & $149 \cdot 6$ & $5 \cdot 0$ & $149 \cdot 1$ & $6 \cdot 8$ & $147 \cdot 3$ & 8.4 & $146 \cdot 3$ & 8.9 & $140 \cdot 7$ & $9 \cdot 3^{* *} \dagger$ & $P<0.1$ \\
\hline & 2.5 & 21 & $148 \cdot 8$ & 4.5 & $148 \cdot 2$ & $7 \cdot 2$ & $147 \cdot 1$ & $9 \cdot 4$ & $143 \cdot 8$ & $8 \cdot 7^{*}$ & $139 \cdot 3$ & $9 \cdot 3^{* *} \dagger$ & $P<0.05$ \\
\hline & 3.6 & 21 & $149 \cdot 1$ & 5.4 & 148.0 & $6 \cdot 3$ & $147 \cdot 7$ & 8.3 & 141.9 & $9 \cdot 0^{* \star} \dagger$ & $135 \cdot 0$ & $10 \cdot 9^{\star \star \star}+\dagger$ & $P<0.001$ \\
\hline & 0.0 & 20 & 89.0 & 4.9 & 88.6 & 3.7 & 87.6 & $6 \cdot 3$ & $87 \cdot 0$ & $7 \cdot 3$ & 87.3 & $7 \cdot 3$ & \\
\hline & 1.8 & 21 & 88.9 & $4 \cdot 8$ & 88.0 & $5 \cdot 7$ & 86.6 & $7 \cdot 0$ & $85 \cdot 2$ & $8 \cdot 1^{*}$ & 84.7 & 8.3 & NS \\
\hline & $2 \cdot 5$ & 21 & 88.5 & $5 \cdot 6$ & 88.4 & $5 \cdot 2$ & 86.9 & $7 \cdot 0$ & $86 \cdot 4$ & 7.6 & 84.9 & 8.5 & NS \\
\hline & 3.6 & 21 & 88.6 & $5 \cdot 0$ & $88 \cdot 1$ & $6 \cdot 2$ & 86.8 & 6.7 & 85.0 & 8.8 & 83.9 & $8 \cdot 8^{*}$ & NS \\
\hline \multicolumn{3}{|c|}{ High-normal blood pressure } & \multicolumn{10}{|c|}{ Systolic blood pressure } & \\
\hline & 0.0 & 12 & 133.2 & 2.5 & $132 \cdot 8$ & $3 \cdot 4$ & $132 \cdot 6$ & $4 \cdot 4$ & $132 \cdot 3$ & $6 \cdot 4$ & $133 \cdot 1$ & 5.5 & \\
\hline & $1 \cdot 8$ & 12 & $134 \cdot 8$ & $2 \cdot 2$ & $134 \cdot 3$ & 3.4 & $132 \cdot 5$ & $6 \cdot 4$ & $132 \cdot 1$ & $8 \cdot 2$ & $132 \cdot 8$ & 9.5 & NS \\
\hline & 2.5 & 12 & 134.5 & $2 \cdot 6$ & $134 \cdot 1$ & 3.5 & $133 \cdot 0$ & $5 \cdot 7$ & 132.5 & 4.5 & $132 \cdot 6$ & $5 \cdot 4$ & NS \\
\hline & & & \multicolumn{10}{|c|}{ Diastolic blood pressure } & \\
\hline & 0.0 & 12 & $81 \cdot 6$ & $2 \cdot 2$ & $80 \cdot 2$ & $2 \cdot 7$ & $80 \cdot 1$ & 3.6 & $80 \cdot 8$ & $6 \cdot 0$ & $79 \cdot 2$ & $4 \cdot 3$ & \\
\hline & $1 \cdot 8$ & 12 & 81.9 & 4.9 & $80 \cdot 8$ & $5 \cdot 6$ & $81 \cdot 2$ & $6 \cdot 4$ & $81 \cdot 7$ & $5 \cdot 7$ & 79.9 & $4 \cdot 8$ & NS \\
\hline & 2.5 & 12 & $81 \cdot 7$ & 3.5 & $82 \cdot 1$ & 4.4 & 81.3 & $5 \cdot 2$ & $80 \cdot 1$ & $6 \cdot 3$ & $80 \cdot 0$ & 6.6 & NS \\
\hline & 3.6 & 12 & $81 \cdot 6$ & 4.6 & $81 \cdot 2$ & $4 \cdot 7$ & 81.9 & 5.0 & $81 \cdot 1$ & 5.7 & 79.8 & 6.0 & NS \\
\hline
\end{tabular}

IPP, Ile-Pro-Pro; VPP, Val-Pro-Pro.

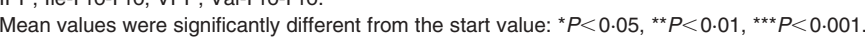

Mean values were significantly different from the control group: $\dagger P<0.05, \dagger \dagger P<0.01$.

A. oryzae hydrolysate was almost the same as that in $L$. helveticus-fermented milk when comparing these ACE inhibitory activities (VPP and IPP, 9 and $5 \mu \mathrm{M}$, respectively; Nakamura et al. 1995a). In this study, the decrease in blood pressure in mildly hypertensive subjects 6 weeks after treatment was $13.0 \mathrm{mmHg}$ with dosages of $3.6 \mathrm{mg}$ VPP and IPP. In a previous study, a daily consumption of $L$. helveticus-fermented milk product containing $3.9 \mathrm{mg}$ VPP and IPP caused a fall in blood pressure of about $12.7 \mathrm{mg}$ in mildly hypertensive subjects 6 weeks after treatment (Kajimoto et al. 2001).

Our study shows that $A$. oryzae hydrolysate and L. helveticusfermented milk have similar antihypertensive effects with almost the same dosage of the two peptides. It also indicates that VPP and IPP are the major active components in the A. oryzae hydrolysate because any slight differences in the composition ratio of VPP/IPP between the fermented milk and the A. oryzae hydrolysate may not affect the antihypertensive effects in human subjects. For the high-normal blood pressure subjects, a significant decrease in blood pressure $(5.5 \mathrm{mmHg})$ in fifty-three subjects with high-normal blood pressure after the daily consumption of a yoghurt-like product containing $3.7 \mathrm{mg}$ VPP and IPP has previously been reported (Nakamura et al. 2002). However, the $A$. oryzae hydrolysate containing $1.8-3.6 \mathrm{mmHg}$ VPP and IPP showed no significant effect on subjects with high-normal blood pressure in this small study ( $n$ 12). Therefore, a large number of volunteers may be necessary to detect significant changes in blood pressure for high-normal subjects in a clinical trial as previously reported (Nakamura et al. 2002). On the other hands, these findings indicate the safety of the A. oryzae hydrolysate because it is active only in hypertensive subjects and not in normotensive people. In conclusion, the A. oryzae hydrolysate had no significant adverse effects throughout the test period and had potential as a functional peptide to reduce CVD and high blood pressure in hypertensive individuals.
Blood pressure continued to decrease in the volunteers during the daily repeated intake of the A. oryzae hydrolysate over the 6 weeks, the effects being greatest 6 weeks after the start of peptide administration. These findings indicate a persistent blood pressure-lowering effect by repeated ingestion of the A. oryzae peptide. A previous paper reported similar results of a mild decrease in blood pressure from the repeated ingestion of VPP and IPP in fermented milk, and a further decrease in blood pressure was measured 4 weeks after treatment had ceased (Hata et al. 1996). To fully understand the mild and persistent clinical efficacy of the A. oryzae hydrolysate observed in this study, pharmacokinetic studies of VPP and IPP should be carried out. Moreover, a longer clinical study period is needed to observe persistent effects of the A. oryzae hydrolysate on hypertensive subjects.

The results of the haematology study showed that the concentration of $\mathrm{Na}^{+}$, albumin and haemoglobin $\mathrm{A}_{1 \mathrm{C}}$ were significantly lower in all groups 6 weeks after treatment. There is no clear answer to explain these results, but these parameters did not seem to affect blood pressure levels because these changes were detected in all the groups. Other changes detected in some parameters in Table $4\left(\mathrm{Ca}^{2+}\right.$, white blood cell count, mean corpuscular haemoglobin and total protein), were not specific to the test sample groups. The correlation of changed parameters shown in Table 4 is therefore not clear.

\section{Acknowledgements}

We would like to thank Dr Yasunori Nakamura and Dr Kohji Ohoki for helpful suggestions throughout this study, and Satoshi Shinozaki and Yuri Nagao for preparing test samples at the Product Development Laboratory, Calpis Co. Ltd. 
Table 4. Haematological and biochemical analysis

(Means and standard deviations)

\begin{tabular}{|c|c|c|c|c|c|c|c|}
\hline & Standard value & Study group & $n$ & Before treatment & SD & After treatment & SD \\
\hline \multirow[t]{4}{*}{ Urea nitrogen (mg/dl) } & $7 \cdot 0-23 \cdot 0$ & Placebo & 32 & $14 \cdot 8$ & $4 \cdot 0$ & $14 \cdot 3$ & $3 \cdot 4$ \\
\hline & & $1.8 \mathrm{mg}$ & 33 & $14 \cdot 1$ & 2.9 & $13 \cdot 4$ & $2 \cdot 6$ \\
\hline & & $2.5 \mathrm{mg}$ & 33 & 14.5 & $4 \cdot 3$ & $13 \cdot 7$ & 3.5 \\
\hline & & $3.6 \mathrm{mg}$ & 33 & $14 \cdot 6$ & $3 \cdot 2$ & $13 \cdot 5$ & $3 \cdot 3^{*}$ \\
\hline \multirow[t]{4}{*}{ Creatinine $(\mathrm{mg} / \mathrm{dl})$} & $0.6-1.5$ & Placebo & 32 & 0.90 & $0 \cdot 17$ & 0.92 & 0.16 \\
\hline & & $1.8 \mathrm{mg}$ & 33 & 0.90 & $0 \cdot 16$ & 0.89 & $0 \cdot 16$ \\
\hline & & $2.5 \mathrm{mg}$ & 33 & 0.92 & $0 \cdot 16$ & 0.89 & $0 \cdot 13^{\star}$ \\
\hline & & $3.6 \mathrm{mg}$ & 33 & 0.95 & 0.17 & 0.93 & 0.16 \\
\hline \multirow[t]{4}{*}{ Uric acid (mg/dl) } & $2 \cdot 0-7 \cdot 5$ & Placebo & 32 & $5 \cdot 10$ & $1 \cdot 18$ & 5.40 & $1 \cdot 19^{\star \star}$ \\
\hline & & $1.8 \mathrm{mg}$ & 33 & 4.99 & $1 \cdot 25$ & 4.96 & $1 \cdot 30$ \\
\hline & & $2.5 \mathrm{mg}$ & 33 & $5 \cdot 24$ & 1.29 & $5 \cdot 16$ & $1 \cdot 13$ \\
\hline & & $3.6 \mathrm{mg}$ & 33 & $5 \cdot 69$ & $1 \cdot 27$ & $5 \cdot 63$ & 1.40 \\
\hline \multirow[t]{4}{*}{$\mathrm{Na}^{+}(\mathrm{mEq} / \mathrm{l})$} & $135-147$ & Placebo & 32 & $141 \cdot 4$ & 1.3 & $139 \cdot 9$ & $1 \cdot 2^{\star \star \star}$ \\
\hline & & $1.8 \mathrm{mg}$ & 33 & $141 \cdot 3$ & 1.5 & $140 \cdot 0$ & $1 \cdot 3^{\star \star *}$ \\
\hline & & $2.5 \mathrm{mg}$ & 33 & 141.4 & $1 \cdot 8$ & $140 \cdot 2$ & $1 \cdot 5^{\star \star}$ \\
\hline & & $3.6 \mathrm{mg}$ & 33 & $141 \cdot 3$ & 1.5 & $140 \cdot 1$ & $1 \cdot 6^{\star \star \star}$ \\
\hline \multirow{3}{*}{$\mathrm{K}^{+}(\mathrm{mEq} / \mathrm{l})$} & & $1.8 \mathrm{mg}$ & 33 & 4.42 & 0.38 & 4.48 & 0.38 \\
\hline & & $2.5 \mathrm{mg}$ & 33 & $4 \cdot 39$ & 0.43 & 4.56 & $0.40 \dagger$ \\
\hline & & $3.6 \mathrm{mg}$ & 33 & 4.48 & 0.45 & 4.42 & 0.35 \\
\hline \multirow[t]{4}{*}{$\mathrm{Cl}^{-}(\mathrm{mEq} / \mathrm{l})$} & $97-107$ & Placebo & 32 & 101.6 & 1.7 & 101.9 & 1.9 \\
\hline & & $1.8 \mathrm{mg}$ & 33 & $101 \cdot 2$ & 1.4 & $101 \cdot 7$ & 1.5 \\
\hline & & $2.5 \mathrm{mg}$ & 33 & $101 \cdot 3$ & $1 \cdot 7$ & $102 \cdot 1$ & $1 \cdot 6^{*}$ \\
\hline & & $3.6 \mathrm{mg}$ & 33 & $100 \cdot 8$ & 1.7 & 101.9 & $1 \cdot 8^{\star \star}$ \\
\hline \multirow[t]{4}{*}{$\mathrm{Ca}^{2+}(\mathrm{mg} / \mathrm{dl})$} & $8.5-11.0$ & Placebo & 32 & $9 \cdot 30$ & 0.36 & $9 \cdot 29$ & 0.34 \\
\hline & & $1.8 \mathrm{mg}$ & 33 & 9.34 & 0.30 & $9 \cdot 19$ & $0.29^{*}$ \\
\hline & & $2.5 \mathrm{mg}$ & 33 & $9 \cdot 34$ & 0.36 & $9 \cdot 29$ & 0.31 \\
\hline & & $3.6 \mathrm{mg}$ & 33 & $9 \cdot 42$ & 0.32 & $9 \cdot 25$ & $0.25^{\star \star}$ \\
\hline \multirow[t]{4}{*}{$\mathrm{Mg}^{2+}(\mathrm{mg} / \mathrm{dl})$} & $1 \cdot 5-2 \cdot 8$ & Placebo & 32 & $2 \cdot 32$ & 0.12 & $2 \cdot 31$ & 0.14 \\
\hline & & $1.8 \mathrm{mg}$ & 33 & $2 \cdot 33$ & $0 \cdot 10$ & $2 \cdot 31$ & $0 \cdot 13$ \\
\hline & & $2.5 \mathrm{mg}$ & 33 & $2 \cdot 31$ & 0.17 & $2 \cdot 31$ & 0.18 \\
\hline & & $3.6 \mathrm{mg}$ & 33 & $2 \cdot 32$ & 0.11 & $2 \cdot 32$ & 0.13 \\
\hline \multirow[t]{2}{*}{ Glutamic-oxaloacetic transaminase (IU/I) } & $10-40$ & Placebo & 32 & $20 \cdot 1$ & $5 \cdot 1$ & $19 \cdot .8$ & $5 \cdot 6$ \\
\hline & & $1.8 \mathrm{mg}$ & 33 & $20 \cdot 2$ & $6 \cdot 5$ & $20 \cdot 0$ & $5 \cdot 2$ \\
\hline \multirow{3}{*}{ Glutamic-pyruvic transaminase (IU/I) } & & $1 \cdot 8 \mathrm{mg}$ & 33 & $21 \cdot 3$ & $13 \cdot 3$ & $21 \cdot 9$ & $12 \cdot 3$ \\
\hline & & $2.5 \mathrm{mg}$ & 33 & $19 \cdot 9$ & $14 \cdot 6$ & $20 \cdot 7$ & $13 \cdot 2$ \\
\hline & & $3.6 \mathrm{mg}$ & 33 & $20 \cdot 9$ & $15 \cdot 6$ & $20 \cdot 7$ & $13 \cdot 3$ \\
\hline \multirow[t]{4}{*}{ Alkaline phosphatase (IU/I) } & $100-325$ & Placebo & 32 & $214 \cdot 3$ & $64 \cdot 3$ & $216 \cdot 1$ & $65 \cdot 0$ \\
\hline & & $1.8 \mathrm{mg}$ & 33 & 198.5 & $52 \cdot 2$ & $195 \cdot 5$ & $51 \cdot 7$ \\
\hline & & $2.5 \mathrm{mg}$ & 33 & $200 \cdot 1$ & $68 \cdot 8$ & $195 \cdot 6$ & $56 \cdot 9$ \\
\hline & & $3.6 \mathrm{mg}$ & 33 & $208 \cdot 1$ & $48 \cdot 3$ & $202 \cdot 9$ & $47 \cdot 8$ \\
\hline$\gamma$-GTP (IU/I) & $80>$ & Placebo & 32 & $38 \cdot 4$ & $54 \cdot 3$ & $40 \cdot 0$ & $63 \cdot 9$ \\
\hline & & $1.8 \mathrm{mg}$ & 33 & $33 \cdot 6$ & 29.5 & $27 \cdot 9$ & $19 \cdot 5^{\star}$ \\
\hline & & $2.5 \mathrm{mg}$ & 33 & $32 \cdot 5$ & $33 \cdot 1$ & $31 \cdot 2$ & $24 \cdot 5$ \\
\hline & & $3.6 \mathrm{mg}$ & 33 & 33.7 & $32 \cdot 2$ & $32 \cdot 2$ & $30 \cdot 4$ \\
\hline Lactate dehydrogenase (IU/I) & $120-240$ & Placebo & 32 & $184 \cdot 4$ & $27 \cdot 1$ & $180 \cdot 0$ & $26 \cdot 1$ \\
\hline & & $1.8 \mathrm{mg}$ & 33 & $186 \cdot 2$ & $28 \cdot 0$ & $181 \cdot 8$ & $34 \cdot 1$ \\
\hline & & $2.5 \mathrm{mg}$ & 33 & $186 \cdot 7$ & $34 \cdot 1$ & $180 \cdot 3$ & $30 \cdot 7$ \\
\hline & & $3.6 \mathrm{mg}$ & 33 & $194 \cdot 6$ & $31 \cdot 4$ & $189 \cdot 9$ & $29 \cdot 2$ \\
\hline Total bilirubin (mg/dl) & $0.2-1 \cdot 0$ & Placebo & 32 & 0.91 & 0.24 & 0.89 & 0.27 \\
\hline & & $1.8 \mathrm{mg}$ & 33 & 0.86 & 0.36 & 0.81 & 0.30 \\
\hline & & $2.5 \mathrm{mg}$ & 33 & 0.89 & 0.25 & 0.88 & 0.24 \\
\hline & & $3.6 \mathrm{mg}$ & 33 & 0.83 & 0.27 & 0.81 & 0.24 \\
\hline White blood cells $\left(\times 10^{2} / \mu \mathrm{l}\right)$ & & Placebo & 32 & $55 \cdot 3$ & $15 \cdot 5$ & 51.8 & 13.0 \\
\hline & $33-90$ & $1.8 \mathrm{mg}$ & 33 & $57 \cdot 2$ & $12 \cdot 5$ & $52 \cdot 1$ & $13 \cdot 0^{\star *}$ \\
\hline & & $2.5 \mathrm{mg}$ & 33 & $56 \cdot 1$ & $13 \cdot 3$ & $51 \cdot 6$ & $10 \cdot 8^{\star}$ \\
\hline & & $3.6 \mathrm{mg}$ & 33 & $54 \cdot 6$ & $11 \cdot 0$ & $50 \cdot 9$ & $13 \cdot 2$ \\
\hline Red blood cells $\left(\times 10^{4} / \mu \mathrm{l}\right)$ & $380-560$ & Placebo & 32 & 465.8 & 31.5 & $466 \cdot 5$ & 34.6 \\
\hline & & $1.8 \mathrm{mg}$ & 33 & $476 \cdot 5$ & $44 \cdot 3$ & 474.4 & $47 \cdot 8$ \\
\hline & & $2.5 \mathrm{mg}$ & 33 & 465.9 & $45 \cdot 8$ & $462 \cdot 3$ & $42 \cdot 4$ \\
\hline & & $3.6 \mathrm{mg}$ & 33 & $465 \cdot 2$ & $46 \cdot 9$ & $457 \cdot 9$ & $43 \cdot 7^{\star}$ \\
\hline Haemoglobin (g/dl) & $12 \cdot 0-17 \cdot 5$ & Placebo & 32 & 13.9 & $1 \cdot 0$ & $14 \cdot 0$ & $1 \cdot 1$ \\
\hline & & $1.8 \mathrm{mg}$ & 33 & $14 \cdot 1$ & 1.5 & $14 \cdot 2$ & $1 \cdot 7$ \\
\hline & & $2.5 \mathrm{mg}$ & 33 & $13 \cdot 8$ & $1 \cdot 7$ & $13 \cdot 8$ & 1.8 \\
\hline & & $3.6 \mathrm{mg}$ & 33 & $14 \cdot 0$ & 1.4 & $13 \cdot 8$ & $1 \cdot 3^{*}$ \\
\hline
\end{tabular}


Table 4. Continued

\begin{tabular}{|c|c|c|c|c|c|c|c|}
\hline & Standard value & Study group & $n$ & Before treatment & SD & After treatment & SD \\
\hline \multirow[t]{4}{*}{ Haematocrit (\%) } & $35 \cdot 0-53 \cdot 0$ & Placebo & 32 & $41 \cdot 7$ & $2 \cdot 8$ & $41 \cdot 8$ & 2.9 \\
\hline & & $1.8 \mathrm{mg}$ & 33 & $42 \cdot 6$ & $4 \cdot 0$ & $42 \cdot 5$ & $4 \cdot 3$ \\
\hline & & $2.5 \mathrm{mg}$ & 33 & $41 \cdot 6$ & $4 \cdot 6$ & 41.4 & 4.5 \\
\hline & & $3.6 \mathrm{mg}$ & 33 & $42 \cdot 2$ & $3 \cdot 8$ & 41.5 & $3 \cdot 5^{\star}$ \\
\hline \multirow[t]{4}{*}{ Mean corpuscular volume (fl) } & $85-100$ & Placebo & 32 & $89 \cdot 1$ & $3 \cdot 1$ & $89 \cdot 3$ & $3 \cdot 0^{*}$ \\
\hline & & $1.8 \mathrm{mg}$ & 33 & $89 \cdot 1$ & $5 \cdot 3$ & $89 \cdot 3$ & $4 \cdot 8$ \\
\hline & & $2.5 \mathrm{mg}$ & 33 & $88 \cdot 8$ & $5 \cdot 2$ & $89 \cdot 1$ & $4 \cdot 8$ \\
\hline & & $3.6 \mathrm{mg}$ & 33 & $90 \cdot 5$ & $4 \cdot 5$ & $90 \cdot 5$ & 4.5 \\
\hline \multirow[t]{4}{*}{ Mean corpuscular haemoglobin (pg) } & $28-34$ & Placebo & 32 & $29 \cdot 3$ & $1 \cdot 1$ & 29.5 & $1 \cdot 2^{\star *}$ \\
\hline & & $1.8 \mathrm{mg}$ & 33 & $29 \cdot 2$ & $2 \cdot 0$ & $29 \cdot 3$ & $2 \cdot 1$ \\
\hline & & $2.5 \mathrm{mg}$ & 33 & $29 \cdot 0$ & $2 \cdot 1$ & $29 \cdot 3$ & $2 \cdot 2^{\star \star}$ \\
\hline & & $3.6 \mathrm{mg}$ & 33 & $29 \cdot 7$ & $1 \cdot 8$ & $29 \cdot 8$ & $1 \cdot 8$ \\
\hline \multirow[t]{4}{*}{ Mean corpuscular haemoglobin concentration (\%) } & $31-35$ & Placebo & 32 & $32 \cdot 8$ & 0.9 & $32 \cdot 9$ & $0 \cdot 8$ \\
\hline & & $1.8 \mathrm{mg}$ & 33 & $32 \cdot 7$ & 0.9 & $32 \cdot 8$ & $1 \cdot 0$ \\
\hline & & $2.5 \mathrm{mg}$ & 33 & $32 \cdot 6$ & 0.9 & $32 \cdot 8$ & $1 \cdot 0^{* *}$ \\
\hline & & $3.6 \mathrm{mg}$ & 33 & $32 \cdot 7$ & 0.8 & $32 \cdot 9$ & 0.8 \\
\hline \multirow{3}{*}{ Platelets $\left(x 10^{4} / \mu \mathrm{l}\right)$} & & $1.8 \mathrm{mg}$ & 33 & $25 \cdot 4$ & $5 \cdot 1$ & 24.9 & 4.9 \\
\hline & & $2.5 \mathrm{mg}$ & 33 & $23 \cdot 6$ & $5 \cdot 4$ & $24 \cdot 4$ & $6 \cdot 1^{*}$ \\
\hline & & $3.6 \mathrm{mg}$ & 33 & 24.5 & $5 \cdot 2$ & $24 \cdot 8$ & $5 \cdot 2$ \\
\hline \multirow[t]{4}{*}{ Total protein $(\mathrm{g} / \mathrm{dl})$} & $6.5-8.5$ & Placebo & 32 & 7.53 & 0.35 & 7.43 & $0.32^{\star}$ \\
\hline & & $1.8 \mathrm{mg}$ & 33 & $7 \cdot 52$ & 0.30 & 7.42 & $0.31^{*}$ \\
\hline & & $2.5 \mathrm{mg}$ & 33 & $7 \cdot 46$ & 0.40 & $7 \cdot 39$ & 0.38 \\
\hline & & $3.6 \mathrm{mg}$ & 33 & $7 \cdot 46$ & 0.30 & $7 \cdot 31$ & $0 \cdot 32^{\star *}$ \\
\hline \multirow[t]{4}{*}{ Albumin (g/dl) } & $3 \cdot 8-5 \cdot 4$ & Placebo & 32 & $4 \cdot 67$ & 0.29 & $4 \cdot 46$ & $0 \cdot 30^{\star \star \star}$ \\
\hline & & $1.8 \mathrm{mg}$ & 33 & $4 \cdot 71$ & 0.22 & $4 \cdot 47$ & $0 \cdot 22^{\star \star \star}$ \\
\hline & & $2.5 \mathrm{mg}$ & 33 & 4.66 & 0.23 & 4.47 & $0 \cdot 16^{\star \star *}$ \\
\hline & & $3.6 \mathrm{mg}$ & 33 & $4 \cdot 64$ & 0.21 & 4.42 & $0 \cdot 18^{\star \star \star}$ \\
\hline \multirow{4}{*}{ Albumin:globulin ratio } & $1 \cdot 1-2 \cdot 0$ & Placebo & 32 & 1.67 & 0.27 & 1.53 & $0.23^{\star \star *}$ \\
\hline & & $1.8 \mathrm{mg}$ & 33 & 1.69 & 0.22 & 1.53 & $0 \cdot 18^{\star \star *}$ \\
\hline & & $2.5 \mathrm{mg}$ & 33 & 1.68 & 0.21 & 1.55 & $0 \cdot 20^{\star * *}$ \\
\hline & & $3.6 \mathrm{mg}$ & 33 & 1.67 & 0.22 & 1.55 & $0 \cdot 21^{* * *}$ \\
\hline \multirow[t]{2}{*}{ Blood sugar (mg/dl) } & $60-110$ & Placebo & 32 & 89.9 & $10 \cdot 0$ & $89 \cdot 7$ & $10 \cdot 7$ \\
\hline & & $1.8 \mathrm{mg}$ & 33 & $89 \cdot 0$ & $9 \cdot 0$ & $89 \cdot 8$ & 7.5 \\
\hline \multirow{3}{*}{ Haemoglobin $\mathrm{A}_{1 \mathrm{C}}(\%)$} & & $1.8 \mathrm{mg}$ & 33 & 4.85 & 0.43 & $4 \cdot 74$ & $0.41^{\star \star \star}$ \\
\hline & & $2.5 \mathrm{mg}$ & 33 & $4 \cdot 80$ & 0.37 & 4.73 & $0 \cdot 40^{\star *}$ \\
\hline & & $3.6 \mathrm{mg}$ & 33 & $4 \cdot 82$ & 0.29 & 4.75 & $0 \cdot 31^{*}$ \\
\hline \multirow{4}{*}{ Total cholesterol (mg/dl) } & $130-220$ & Placebo & 32 & $210 \cdot 5$ & $41 \cdot 4$ & 211.5 & $39 \cdot 5$ \\
\hline & & $1.8 \mathrm{mg}$ & 33 & $204 \cdot 6$ & 34.6 & $204 \cdot 7$ & $30 \cdot 3$ \\
\hline & & $2.5 \mathrm{mg}$ & 33 & $210 \cdot 0$ & $41 \cdot 0$ & $211 \cdot 7$ & $42 \cdot 3$ \\
\hline & & $3.6 \mathrm{mg}$ & 33 & $208 \cdot 8$ & $36 \cdot 1$ & $209 \cdot 7$ & 34.9 \\
\hline \multirow[t]{4}{*}{ HDL-cholesterol (mg/dl) } & $35-90$ & Placebo & 32 & $58 \cdot 3$ & $12 \cdot 3$ & $58 \cdot 2$ & $12 \cdot 5$ \\
\hline & & $1.8 \mathrm{mg}$ & 33 & $64 \cdot 4$ & $16 \cdot 7$ & $64 \cdot 7$ & $17 \cdot 9$ \\
\hline & & $2.5 \mathrm{mg}$ & 33 & $60 \cdot 0$ & $15 \cdot 8$ & $60 \cdot 9$ & $15 \cdot 9$ \\
\hline & & $3.6 \mathrm{mg}$ & 33 & $61 \cdot 5$ & 14.5 & $60 \cdot 7$ & 14.5 \\
\hline \multirow[t]{4}{*}{ Triacylglycerol (mg/dl) } & $40-150$ & Placebo & 32 & 88.5 & 34.6 & $90 \cdot 4$ & $45 \cdot 3$ \\
\hline & & $1.8 \mathrm{mg}$ & 33 & $102 \cdot 6$ & $69 \cdot 0$ & $89 \cdot 7$ & $54 \cdot 9^{\star}$ \\
\hline & & $2.5 \mathrm{mg}$ & 33 & $99 \cdot 3$ & 38.5 & $99 \cdot 1$ & 68.5 \\
\hline & & $3.6 \mathrm{mg}$ & 33 & $92 \cdot 9$ & $61 \cdot 8$ & $95 \cdot 7$ & $64 \cdot 3$ \\
\hline
\end{tabular}

GTP, glutamyltranspeptidase.

Mean values were significantly different from the start value: ${ }^{*} P<0.05,{ }^{* *} P<0.01,{ }^{* \star *} P<0.001$ (paired $t$ test).

Mean values were significantly different from the placebo group: $\dagger P<0.05$ ( $t$ test).

\section{References}

Atkinson AB, Brown JI, Lever AF \& Robertson JI (1980) Combined treatment of severe intractable hypertension with captopril and diuretic. Lancet 2, 105-107.

Chalmers J, Macmahon S, Mancia G, Whitworth J, Beilin L, Hansson L, Neal B, Rodgers A, Ni Mhurchu C \& Clark T (1999) World Health Organisation-International Society of Hypertension guidelines for the management of hypertension. Clinical and Experimental Hypertension 21, 1009-1060.

Conlin PR, Chow D, Miller ER 3rd, Svetkey LP, Lin PH, Harsha DW, Moore TJ, Sacks FM \& Appel LJ (2000) The effect of dietary patterns on blood pressure control in hypertensive patients: results from the Dietary Approaches to Stop Hypertension (DASH) trial. Am J Hypertension 13, 949-955.

Ferguson RK, Vlasses PH, Koplin JR, Shirinian A, Burke JF Jr \& Alexande JC (1980) Captopril in severe treatment-resistant hypertension. Am Heart J 99, 579-585.

Hata Y, Yamamoto M, Ohni M, Nakajima K, Nakamura Y \& Takano T (1996) A placebo-controlled study of the effect of sour milk on blood pressure in hypertensive subjects. Am J Clin Nutr 64, 767-771.

Kajimoto O, Aihara K, Hirata H, Takahashi R \& Nakamura Y (2001) Hypertensive effects of the tablets containing 'Lactotripeptides (VPP, IPP)'. J Nutr Food (Japan) 4, 51-61. 
Kawasaki T, Seki E, Osajima K, Yoshida M, Asada K, Matsui T \& Osajima Y (2000) Antihypertensive effect of valyl-tyrosine, a short chain peptide derived from sardine muscle hydrolyzate, on mild hypertensive subjects. J Hum Hypertens 14, 519-523.

Maeno M, Yamamoto N \& Takano T (1996) Identification of an antihypertensive peptide from casein hydrolyzate by a proteinase from Lactobacillus helveticus CP790. J Dairy Sci 79, 1316-1321.

Maruyama S, Nakagomi K, Tomizuka N \& Suzuki H (1985) Angiotensin I-converting enzyme inhibitor derived from an enzymatic hydrolysate of casein. II. Isolation and bradykinin-potentiating activity on the uterus and the ileum of rats. Agric Biol Chem 49, 1405-1409.

Masuda O, Nakamura Y \& Takano T (1996) Antihypertensive peptides are present in aorta after oral administration of sour milk containing these peptides to spontaneously hypertensive rats. $J$ Nutr $\mathbf{1 2 6}$, 3063-3068

Matsumura N, Fujii M, Takeda Y, Sugita K \& Shimizu T (1993) Angiotensin I-converting enzyme inhibitory peptides derived from bonito bowels autolysate. Biosci Biotech Biochem 57, 695-697.

Matsuura K, Gotou T, Mizuno S, Nishimura S \& Yamamoto N (2005) Quantitative analysis of antihypertensive peptides, Val-Pro-Pro and Ile-Pro-Pro, in casein hydrolyzate using an Aspergillus oryzae protease: an LC-MS method. Milchwissenschaft 60, 24-27.

Meisel H \& Bockelmann W (1999) Bioactive peptides encrypted in milk proteins: proteolytic activation and thropho-functional properties. Antonie van Leewenhoek 76, 207-215.

Miyoshi S, Ishikawa H, Kaneko T, Fukui F, Tanaka H \& Maruyama S (1991) Structures and activity of angiotensin-converting enzyme inhibitors in an alpha-zein hydrolysate. Agric Biol Chem 55, 1313-1318.

Mizuno S, Nishimura S, Matsuura K, Gotou T \& Yamamoto N (2004) Release of short and proline rich antihypertensive peptides from casein hydrolyzate with an Aspergillus oryzae protease. J Dairy Sci 87, 3183-3188.

Moore TJ, Vollmer WM, Appel LJ, et al. (1999) Effect of dietary patters on ambulatory blood pressure: results from the Dietary Approaches to Stop Hypertension (DASH) trial: DASH collaborative research group. Hypertension 34, 472-477.

Nakamura Y, Kajimoto O, Kaneko K, Aihara K, Mizutani J, Ikeda N \& Kajimoto Y (2002) Effect of the liquid yogurts containing 'lactotripeptide (VPP and IPP)' on high-normal blood pressure. J Nutr Food (Japan) 5, 55-66.
Nakamura Y, Masuda O \& Takano T (1996) Decrease of tissue angiotensinI-converting enzyme activity upon feeding sour milk in spontaneously hypertensive rats. Biosci Biotech Biochem 60, 488-489.

Nakamura Y, Yamamoto N, Sakai K, Okubo A, Yamazaki S \& Takano T (1995a) Purification and characterization of angiotensin I-converting enzyme inhibitors from sour milk. J Dairy Sci 78, 777-783.

Nakamura Y, Yamamoto N, Sakai K \& Takano T (1995b) Antihypertensive effect of sour milk and peptides isolated from it that are inhibitors to angiotensin I-converting enzyme. J Dairy Sci 78, 1253-1257.

Seppo L, Jauhiainen T, Poussa T \& Korpela R (2003) A fermented milk high in bioactive peptides has a blood pressure-lowering effect in hypertensive subjects. Am J Clin Nutr 77, 326-330.

Seppo L, Kerojoki O, Suomalainen T \& Korpela R (2002) The effect of a Lactobacillus helveticus LBK-16 H fermented milk on hypertension a pilot study on humans. Milchwissenschaft 57, 124-127.

Staessen J (1981) The hypotensive effect of propranolol in captopril-treated patients does not involve the plasma renin-angiotensin-aldosterone system. Clin Sci 61, 441-444.

Stornello M, Di Rao G, Iachello M, et al. (1983) Hemodynamic and humoral interactions between captopril and nifedipine. Hypertension 5, 154-156.

Svetkey LP, Moore TJ, Simons-Morton DG, et al. (2001) DASH collaborative research group Angiotensinogen genotype and blood pressure response in the dietary approaches to top hypertension (DASH) study. $J$ Hypertens 19, 1949-1956.

Takano T (1998) Milk derived peptides and hypertension reduction. Int Dairy J 8, 375-381.

Yamamoto N, Akino A \& Takano T (1994) Antihypertensive effects of different kinds of fermented milk in spontaneously hypertensive rats. Biosci Biotech Biochem 58, 776-778.

Yamamoto N, Ejiri M \& Mizuno S (2003) Biogenic peptides and their potential use. Curr Pharmaceut Design 9, 1345-1355.

Yamamoto N \& Takano T (1999) Antihypertensive peptides derived from milk proteins. Nahrung 43, 159-164.

Yamamoto N, Maeno M \& Takano T (1999) Purification of the antihypertensive peptide from yogurt-like product. J Dairy Sci 82, 1388-1393.

Yokoyama K, Chiba H \& Yoshikawa M (1992) Peptide inhibitors for angiotensin I-converting enzyme from thermolysin digest of dried bonito. Biosci Biotechnol Biochem 56, 1541-1545. 